\title{
POTENTIAL ANTIOXIDANT, ANTI-INFLAMMATORY AND ANTIBACTERIAL EVALUATION OF EXTRACTS OF LEUCAS ASPERA USING IN VITRO MODELS
}

\author{
TAHAREEN S., SHWETHA R., MYRENE R. D. * \\ Department of Chemistry (P. G. Biochemistry), Mount Carmel College, Palace Road, Bengaluru, India 560052 \\ Email: myrene83@gmail.com
}

Received: 27 Jun 2016 Revised and Accepted: 09 Sep 2016

\section{ABSTRACT}

Objective: To evaluate the potential antioxidant, anti-inflammatory and antibacterial activities of aqueous and methanolic extracts of leaves of Leucas aspera (Thumbae).

Methods: Phytochemical screening of the leaves of $L$. aspera was followed by analysis of antioxidant activity by means of DPPH (2, 2-diphenyl-1picrylhydrazyl) radical scavenging activity. In vitro anti-inflammatory activity was evaluated using lipoxygenase inhibition, albumin denaturation assay, membrane stabilization assay and proteinase inhibitory activity at different concentrations. Aspirin was used as a standard drug for the study of anti-inflammatory activity. Linear regression analysis was used to calculate half maximal inhibitory concentration, IC50 value. The zone of inhibition was performed against common pathogens to determine the antimicrobial activity at different concentrations of plant extracts $(60 \%$, $70 \%, 80 \%)$

Results: The phytochemical analysis revealed the presence of carbohydrates, amino acid, alkaloids, tannins, flavonoids, glycosides, xanthoproteins, and phenols. The total phenolic and flavonoid content was found to be $2.25 \pm 0.04 \mathrm{mg}$ GAE/g (gallic acid equivalents) and $1.2 \pm 0.05 \mathrm{mg}$ QE/g (Quercetin equivalents) of fresh weight tissue respectively. The IC50 values for hydrogen peroxide scavenging activity were found to be 244.6 $\mu \mathrm{g} / \mathrm{ml}$. The extract inhibited the lipoxygenase enzyme activity with an IC50 value of $356.3 \mu \mathrm{g} / \mathrm{ml}$. Maximum inhibition of heat-induced protein denaturation of $69 \%$ was observed at $400 \mu \mathrm{g} / \mathrm{ml}$, IC50 $249.6 \mu \mathrm{g} / \mathrm{ml}$. Proteinase activity was also significantly inhibited (IC50 $=421.6 \mu \mathrm{g} / \mathrm{ml}$ ). Membrane stabilization assay attributed minor protection by the leaf extract with an IC50 of 206.7. It was observed that $E$. coli were inhibited at all concentrations, followed by Klebsiella and Pseudomonas.

Conclusion: Results indicate that L. aspera possess anti-inflammatory properties due to the strong occurrence of polyphenolic compounds such as alkaloids, flavonoids, tannins and steroids that serve as free radical inhibitors or scavenger. Compounds of the plant L. aspera may hence be used as lead compounds for designing potent anti-inflammatory drug which can be used for treatment of various diseases.

Keywords: Albumin denaturation, Anti-inflammatory, Antimicrobial, Hemolysis, lipooxygenase, Phytochemicals, Leucas aspera

(C) 2016 The Authors. Published by Innovare Academic Sciences Pvt Ltd. This is an open access article under the CC BY license (http://creativecommons. org/licenses/by/4. 0/] DOI: http://dx.doi.org/10.22159/ijpps.2016v8i11.13711

\section{INTRODUCTION}

The rich biodiversity of Indian subcontinent contributes to the wealth of medicinal plants, which are very much used in traditional medical treatments [1]. India is one of the 12 mega biodiversity centers with over 18,000 plant species. Over 2,500 species are formally recognized as having true medicinal value. About 7500 plants have been used in local health traditions in rural and tribal villages of India. Out of these, the medicinal efficacy of 4000 plants is either little known or unknown to the mainstream population [1]. About 1500 plants with medicinal uses are mentioned in ancient texts such as Ayurveda, Siddha, Unani and Tibetan medicine. In recent years, the growing demand for herbal products has led to a quantum jump in volume of plant materials traded within and across various countries in the world.

The plants of genus Leucas have been used by the tribals in various parts of Asia, Africa, and India. Hot water extract of L. aspera is used orally as a stimulant, laxative, and diuretic [2], for the treatment of a headache, asthma, and bronchitis [3]. Hot water extract of the entire plant is also used to treat inflammation, dyspepsia, and jaundice [4]. Entire plant extract is used orally to treat scabies, psoriasis, and snake bite [5]. The plant L. aspera is externally used as an insect repellent [6]. L. aspera are externally used to fumigate dwellings [5]. A handful of flowers roasted in ghee are given orally (5-10 g once a day) for the treatment of a cough and colds. The flowers are crushed, and aroma is inhaled in the opposite nostril for the relief of a migraine. The juice of leaves is used aurally for ear pain [7] and for pus discharge from ear. The paste of leaves ground with chalk is applied to tooth cavity (periodontal) to prevent decay. The decoction of leaves is used nasally as an antivenin. Infusion of leaves is used externally to treat scabies [8]. Leaf paste mixed with turmeric is used to heal wounds and boils [9]. The decoction of roots, stem, and inflorescence of L. aspera are used orally for high fevers [10], for influenza [11] and against the filarial parasite [5]

Current research on natural molecules and products primarily focuses on plants since they can be sourced more easily and selected on the basis of their ethnomedicinal use [12]. Primary bioassays are generally designed for rapid screening of large numbers of products or extracts. They are simple, easy to implement and produce results quickly and preferably at low cost. With this under consideration, $L$. aspera was chosen for in vitro studies. It is widely used India as foods and also for the nutritional requirement. Mukherjee et al., [13] reported that the ethanol extract of aerial part of Leucas significantly reduced the incidence and severity of diarrhoea in the castor oilinduced diarrhoea in rats. Antidiabetic activity has established that the methanol extracts of the whole plant of Leucas possess a doserelated strong hypoglycemic activity and have a similar potency to that of glibenclamide at an oral dose of $400 \mathrm{mg} / \mathrm{kg}$ [14]. The cold methanolic extract of the whole plant of Leucas aspera was found to exhibit significant hepatoprotection in $\mathrm{CCl}_{4}$ induced liver damage [15]. Various studies using the brine shrimp lethality assay showed that the hydroalcoholic extract of $L$. aspera whole plant exhibited cytotoxicity [16]. L. aspera leaf extract exhibited significant larvicidal activity against first, second, third and fourth instar larvae of Culex quinquefasciatus [17].

The development of bacterial resistance to presently available antibiotics has necessitated the need to search for new antibacterial agents. Multiple drug resistance in human pathogenic microorganisms has been developed due to indiscriminate use of 
commercial antimicrobial drugs commonly used in the treatment of infectious diseases [18]. The development of antibiotic resistance is multifactorial, including the specific nature of the relationship of bacteria to antibiotics, the usage of an antibacterial agent, host characteristics and environmental factors. This situation has forced scientists to search for new antimicrobial substances from various sources as novel antimicrobial chemotherapeutic agents, but the cost production of synthetic drugs is high and they produce adverse effects compared to plant-derived drugs [19]. The aqueous extract of the leaves of Leucas was found to be inactive against fungal strainsAspergillus flavus [20], Trichophyton rubrum, Aspergillus niger [21]. Significant antimicrobial activity was also reported for the alkaloidal fraction and the total methanol extract the Leucas flowers [15]. Conflicting antimicrobial activities of Leucas leaves by a number of researchers may be due to variation in the constituents and/or compositions of the different extracts.

This study aimed to screen the plant for its phytochemical constituents in aqueous and methanolic extracts. It evaluates the antioxidant potential and anti-inflammatory nature of the leaf extract in comparison with the commercial standard antioxidant, ascorbic acid. The study also investigated the antibacterial activity of the extract using the reference antibiotic ciprofloxacin.

\section{MATERIALS AND METHODS}

\section{Preparation of plant extract}

The plant samples were obtained from University of Agricultural Sciences, GKVK campus, Bengaluru, India. The plant extracts were prepared using aqueous methanol and water. Fresh leaves were washed thoroughly in distilled water 3-4 times and air dried. $500 \mathrm{mg}$ of leaf sample was homogenized in $10 \mathrm{ml}$ of the selected solvent using mortar and pestle. The crude extracts were then centrifuged at $8000 \mathrm{rpm}$ for $10 \mathrm{~min}$; the supernatant was collected and stored in cold condition.

\section{Chemicals, reagents and solvents}

All chemicals used were of analytical grade and include: methanol (Sigma-Aldrich, Germany), Quercetin (Sigma-Aldrich, Germany), Bovine serum albumin, distilled water, chloroform, Folin-Ciocalteu reagent, hydrogen peroxide, sodium hydroxide $(\mathrm{NaOH})$, potassium ferricyanide ( $\mathrm{K} 3[\mathrm{Fe}(\mathrm{CN}) 6])$, trichloroacetic acid $(\mathrm{C}(\mathrm{Cl} 3) \mathrm{COOH}$; TCA), ferric chloride $\left(\mathrm{FeCl}_{3}\right)$, ascorbic acid, $\alpha, \alpha$-diphenyl- $\beta$-dipicrylhydrazyl (DPPH) radical, buffer tablets.

\section{Equipment/Instruments}

The equipment/instruments used include: electrical weighing balance (Shimadzu, AUW-D Series), analytical weighing balance, digital $\mathrm{pH}$ meter, centrifuge tubes, incubator, centrifuge (Remi, India), test tube racks, UV-Visible spectrophotometer (Systronics, $\mu$ Controller Based UV-VIS Type: 117), soxhlet apparatus, and rotary evaporator (B. Bran Scientific and Instruments Co., England).

\section{Phytochemical screening}

Phytochemical examinations were carried out for all the extracts as per the standard methods [22-24].

\section{Total phenolic content}

Total phenolic contents were estimated according to the spectrophotometric method [25]. A methanolic solution of the extract in the concentration of $1 \mathrm{mg} / \mathrm{ml}$ was taken for estimation. The reaction mixture was prepared by mixing $0.5 \mathrm{ml}$ of a methanolic solution of extract, $2.5 \mathrm{ml}$ of $10 \%$ Folin-Ciocalteu's reagent and 2.5 $\mathrm{ml} 7.5 \% \mathrm{NaHCO}_{3}$. Blank was concomitantly prepared, containing 0.5

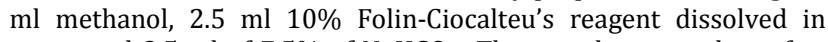
water and $2.5 \mathrm{ml}$ of $7.5 \%$ of $\mathrm{NaHCO}_{3}$. The samples were thereafter incubated in a thermostat at $45^{\circ} \mathrm{C}$ for $45 \mathrm{~min}$. The absorbance was determined using spectrophotometer at $\lambda_{\max }=765 \mathrm{~nm}$. The samples were prepared in triplicate for each analysis and the mean value of absorbance was obtained. The above procedure was repeated for the standard solution of gallic acid, and the calibration line was construed. Based on the measured absorbance, the concentration of phenolics was read $(\mathrm{mg} / \mathrm{ml})$ from the calibration line; the content of phenolics in extracts was expressed in terms of gallic acid equivalent (mg of GAE/g of tissue).

\section{Total flavonoid content}

The aluminum chloride colorimetric method was used for determination of total flavonoids [26]. The plant extract in methanol was mixed with $1.5 \mathrm{ml}$ of methanol, $0.1 \mathrm{ml}$ of $10 \%$ aluminum chloride, $0.1 \mathrm{ml}$ of $1 \mathrm{M}$ potassium acetate and $2.8 \mathrm{ml}$ of distilled water. It was incubated at room temperature for $30 \mathrm{~min}$. The absorbance of the reaction mixture was measured at $415 \mathrm{~nm}$ in triplicate. Sample blank was prepared in a similar way by replacing aluminum chloride with distilled water. The calibration curve was prepared by preparing quercetin solutions at concentrations $6.25,12.5,25,50,80$ and 100 $\mu \mathrm{g} / \mathrm{ml} .10$ to $100 \mu \mathrm{g} / \mathrm{ml}$ in methanol. The flavonoid content in extracts was expressed in terms of quercetin equivalent ( $\mathrm{mg}$ of $\mathrm{QE} / \mathrm{g}$ of tissue).

\section{Evaluation of antioxidant activity}

\section{DPPH radical scavenging activity}

The procedure of Braca [27] was used for determination of DPPH scavenging capacity of various fractions. A stock solution of ascorbic acid $(1000 \mu \mathrm{g} / \mathrm{ml})$ was diluted ranging from $10-100 \mu \mathrm{g} / \mathrm{ml} .0 .1 \mathrm{ml}$ solution from different dilutions was pipetted out in respective tubes. The volume in each tube was made up to $3 \mathrm{ml}$ with DPPH (20 $\mu \mathrm{g} / \mathrm{ml}$ ). The test tubes were incubated for $10 \mathrm{~min}$ at room temperature. The contents of each tube were mixed well and the absorbance was measured at $517 \mathrm{~nm}$ against a blank. A control (3.1 $\mathrm{ml}$ DPPH) was prepared. The percentage inhibition of DPPH by the samples was calculated as follows:

$$
\text { Scavenging effect }(\%)=\frac{\text { (OD of control }- \text { OD of sample) }}{\text { OD of control }} \times 100
$$

\section{Hydrogen peroxide scavenging activity}

Scavenging of hydrogen peroxide was assayed according to the method of Ruch [28]. Plant extract at $30 \mu \mathrm{g} / \mathrm{ml}$ concentration in 3.4 ml phosphate buffer was added to $0.6 \mathrm{ml}$ of $45 \mathrm{mmol} \mathrm{H}_{2} \mathrm{O}_{2}$ solution absorbance of the reaction mixture was recorded at $230 \mathrm{~nm}$. A blank solution contained the sodium phosphate buffer without $\mathrm{H}_{2} \mathrm{O}_{2}$. Ascorbic acid was used as a standard. The concentration of $\mathrm{H}_{2} \mathrm{O}_{2}$ $(\mathrm{mM})$ in the assay medium was determined using a standard curve $\left(\mathrm{y}=0.123 \mathrm{x}+2.2 ; \mathrm{R}^{2}=0.9583\right) \cdot \mathrm{H}_{2} \mathrm{O}_{2}$ scavenging ability was calculated as IC50. The scavenging effect was calculated as follows:

$$
\text { Scavenging effect }(\%)=\frac{\text { (OD of control }- \text { OD of sample) }}{\text { OD of control }} \times 100
$$

\section{Evaluation of in vitro anti-inflammatory activity}

\section{Lipoxygenase inhibition}

Soybean lipoxygenase activity was assayed by the procedure of Axelrod [29]. Briefly, the reaction was carried out in a final volume of $3 \mathrm{ml}$ containing $2.9 \mathrm{ml}$ of $0.1 \mathrm{M}$ borate buffer $\mathrm{pH} 9.0$ and $50 \mu \mathrm{l}$ of 10 mmol Linoleic acid. The reaction was started by the addition of $50 \mu \mathrm{l}$ of the soybean enzyme extract. The enzyme activity was measured by following the formation of the product, 12-HETE at $234 \mathrm{~nm}$ for up to $1 \mathrm{~min}$. The enzyme inhibition was determined by preincubating the enzyme with the plant extract or standard phytochemicals prior to determining its 12-LOX activity. The results are expressed as percent inhibition of the 12-LOX activity.

\section{Inhibition of heat-induced protein denaturation}

The anti-inflammatory activity was studied by using inhibition of albumin denaturation technique $[30,31]$ followed with minor modifications. The reaction mixture was consisting of test extracts and $1 \%$ aqueous solution of bovine albumin fraction, $\mathrm{pH}$ of the reaction mixture was adjusted using a small amount of $1 \mathrm{~N} \mathrm{HCl}$. The sample extracts were incubated at $37^{\circ} \mathrm{C}$ for $20 \mathrm{~min}$ and then heated to $51^{\circ} \mathrm{C}$ for $20 \mathrm{~min}$, after cooling the samples the turbidity was measured at $660 \mathrm{~nm}$. The experiment was performed in triplicate. The Percentage inhibition of protein denaturation was calculated as follows:

$$
\text { Percentage inibition }(\%)=\frac{\text { (OD of control }- \text { OD of sample) }}{\text { OD of control }} \times 100
$$


Proteinase Inhibitory Action: The test was performed according to the modified method [32]. The reaction mixture $(2 \mathrm{ml})$ was containing $0.06 \mathrm{mg}$ trypsin, $1 \mathrm{ml} 20 \mathrm{mmol}$ Tris- $\mathrm{HCl}$ buffer (pH 7.4) and $1 \mathrm{ml}$ test sample of different concentrations $(100-500 \mu \mathrm{g} / \mathrm{ml})$. The mixture was incubated at $37^{\circ} \mathrm{C}$ for $5 \mathrm{~min}$ and then $1 \mathrm{ml}$ of $0.8 \%$ $(\mathrm{w} / \mathrm{v})$ casein was added. The mixture was incubated for an additional $20 \mathrm{~min} .2 \mathrm{ml}$ of $70 \%$ perchloric acid was added to arrest the reaction. Cloudy suspension was centrifuged, and the absorbance of the supernatant was read at $210 \mathrm{~nm}$ against buffer as blank. The experiment was performed in triplicate. The percentage inhibition of proteinase inhibitory activity was calculated.

$$
\text { Percentage inibition }(\%)=\frac{(\text { OD of control }- \text { OD of sample) }}{\text { OD of control }} \times 100
$$

\section{hRBC (human red blood cell) membrane stabilization activity}

The test was performed according to the method of Azeem [33]. Different concentration of extract $(100-500 \mu \mathrm{g} / \mathrm{ml})$, reference sample, and control were separately mixed with $1 \mathrm{ml}$ of phosphate buffer, $2 \mathrm{ml}$ of hyposaline and $0.5 \mathrm{ml}$ of hRBC suspension. Diclofenac sodium $(100 \mu \mathrm{g} / \mathrm{ml})$ was used as a standard drug. All the assay mixtures were incubated at $37^{\circ} \mathrm{C}$ for $30 \mathrm{~min}$ and centrifuged at 3000 $\mathrm{rpm}$. The supernatant liquid was decanted, and the hemoglobin content was estimated by a spectrophotometer at $560 \mathrm{~nm}$. The percentage hemolysis was estimated by assuming the hemolysis produced in control as $100 \%$.

$$
\text { Percentage inibition }(\%)=\frac{\text { (OD of control }- \text { OD of sample) }}{\text { OD of control }} \times 100
$$

\section{Screening of antimicrobial activity}

The antibacterial activity was carried out by employing $48 \mathrm{~h}$ cultures of Staphylococcus aureus, Escherichia coli, Pseudomonas aeruginosa and Klebsiella pneumoniae. The activity of aqueous and methanolic extracts of different concentrations $60,70,80 \%$ of $L$. aspera was tested separately using Agar well diffusion method. The medium was sterilized by autoclaving at $120{ }^{\circ} \mathrm{C}\left(15 \mathrm{lb} / \mathrm{in}^{2}\right)$. About $30 \mathrm{ml}$ of the Agar medium was poured in respective sterile Petri plates and were left at room temperature for solidification. $1 \mathrm{ml}$ of the respective test cultures were swabbed on the top of the solidified media and allowed to dry for $10 \mathrm{~min}$. A well of $6 \mathrm{~mm}$ diameter was made using a sterile cork borer. The standard drug and extracts were placed in the well. Antibacterial assay plates were for overnight incubation. Ciprofloxacin $(50 \mu \mathrm{g} /$ disc $)$ was used as a positive control for antibacterial activity. After $24 \mathrm{~h}$ of incubation at $37{ }^{\circ} \mathrm{C}$, Zone of Inhibition (ZOI) was observed and diameter measured.

\section{Statistical analysis}

Data of in vitro assays recorded were analyzed using Microsoft Excel to determine IC50. One-way analysis of variance (ANOVA) was conducted and $P$ value less than 0.05 was considered as significantly different.

\section{RESULTS AND DISCUSSION}

\section{Preliminary phytochemical screening}

Secondary metabolites contribute significantly towards the biological activities of medicinal plants such as hypoglycemic, antidiabetic, antioxidant, antimicrobial, anti-inflammatory, anticarcinogenic, antimalarial, anticholinergic, antileprosy activities, etc. [34]. The qualitative analysis of extracts of $L$. aspera was carried out and extracts showed the presence of various chemical constituents such as alkaloids, carbohydrates, saponins, glycosides, steroids, flavonoids, phenolics and tannins (table 1).

Our results indicate the presence of phytochemicals in the order of methanolic>aqueous extract (table 1). This shows a high level of its possible medicinal value. Our results are similar to those reported in Tinospora cordifolia [35]. The presence of tannins in L. aspera has been attributed to the plant's ability to hasten the healing of wounds and inflamed mucous membranes. Flavonoids are free radical scavengers that prevent oxidative cell damage, possess strong anticancer activity and diabetes-induced oxidative stress [36]. Saponins, seen only in the methanolic extract possess the unique property of precipitating and coagulating red blood cells [37]. Steroids are known to regulate the immune response as well as reduce cholesterol [38]. The relatively higher amounts of alkaloids seen in methanolic extract have been implicated for its diuretic role and in the reduction of appetite [39]. Thus preliminary phytochemical screening has shown the presence of antioxidant components and other bioactive compounds which might be responsible for the use of the plant in ameliorating inflammatory ailments [40].

\begin{tabular}{|c|c|c|c|c|}
\hline \multirow[t]{2}{*}{ S. No. } & \multirow[t]{2}{*}{ Phytochemical test } & \multirow[t]{2}{*}{ Reagents used (test performed) } & \multicolumn{2}{|l|}{ Results } \\
\hline & & & Aqueous extract & Methanolic extract \\
\hline \multirow[t]{3}{*}{1} & Alkaloid test & Mayer's test & + & ++ \\
\hline & & Wagner's test & + & ++ \\
\hline & & Dragendoroff's test & + & ++ \\
\hline \multirow[t]{3}{*}{2} & Carbohydrate test & Molish's test & + & + \\
\hline & & Benedict's test & + & + \\
\hline & & Fehling's test & + & + \\
\hline 3 & Saponin test & Foam test & - & + \\
\hline 4 & Glycosides test & Borntrager's test & + & ++ \\
\hline 5 & Steroid test & Salkowski test & + & + \\
\hline 6 & Flavonoid test & Lead acetate test & + & ++ \\
\hline 7 & $\begin{array}{l}\text { Proteins and amino } \\
\text { acids }\end{array}$ & Xanthoproteic test & + & + \\
\hline 8 & Tannins test & Ferric chloride test & + & ++ \\
\hline 9 & Terpenoids test & Salkowski test & - & - \\
\hline
\end{tabular}

Table 1: Phytochemical investigation of $L$. aspera leaves $(n=3)$

-indicates absence,+denotes average,++means abundance of phytochemicals

Total phenolic, flavonoid contents, and DPPH scavenging potential

The role of phenolics in biological activity has been reported by several researchers [41]. They are a good electron and hydrogen atom donors having the ability to terminate radical chain reaction involved in lipid peroxidation by converting free radicals and reactive oxygen species to more stable products. The content of phenolic compounds in the methanolic extract was calculated using the standard curve of Gallic acid $\left(y=1.03 x-0.0067 ; R^{2}=0.999\right)$ and is expressed as Gallic acid equivalent (GAE) per gram of plant extract (fig. 1A).

The total phenolic contents of $L$. aspera extract was found to be $2.25 \pm 0.04 \mathrm{mg} \mathrm{GAE} / \mathrm{g}$ of fresh weight tissue (table 2). Consumption of leaves of $L$. aspera rich in these polyphenolic constituents may have the property to counteract oxidative stress related disorders. 
Total flavonoid content was calculated using the standard curve of quercetin ( $\mathrm{y}=0.0035 \mathrm{x}-0.0086 ; \mathrm{R}^{2}=0.988$ ) (fig. 1B) and found to be $1.2 \pm 0.05 \mathrm{mg} \mathrm{QE} / \mathrm{g}$ of fresh weight tissue (table 2).

In the quantitative phytochemical analysis, phenolic content was much more than the flavonoid content (table 2). Flavonoids have been implicated for its role in preventing lipid peroxidation, in ironchelation and free radical scavenging [42-44].
Total antioxidant capacity of the extracts was calculated using \% inhibition against concentration of ascorbic acid $\left(\mathrm{y}=0.8561 \mathrm{x} ; \mathrm{R}^{2}=\right.$ 0.826) (fig. 1C). At $100 \mu \mathrm{g} / \mathrm{ml}$ concentration, L. aspera (40\%) exhibited maximum DPPH radical scavenging activity that was found to be $80.69 \pm 3.68$ (table 2). The presence of secondary metabolites in the extract resulted in a significant decrease in in vitro DPPH/ concentration by reducing the stable DPPH radical to a yellowish colored diphenyl picrylhydrazine derivative [45].
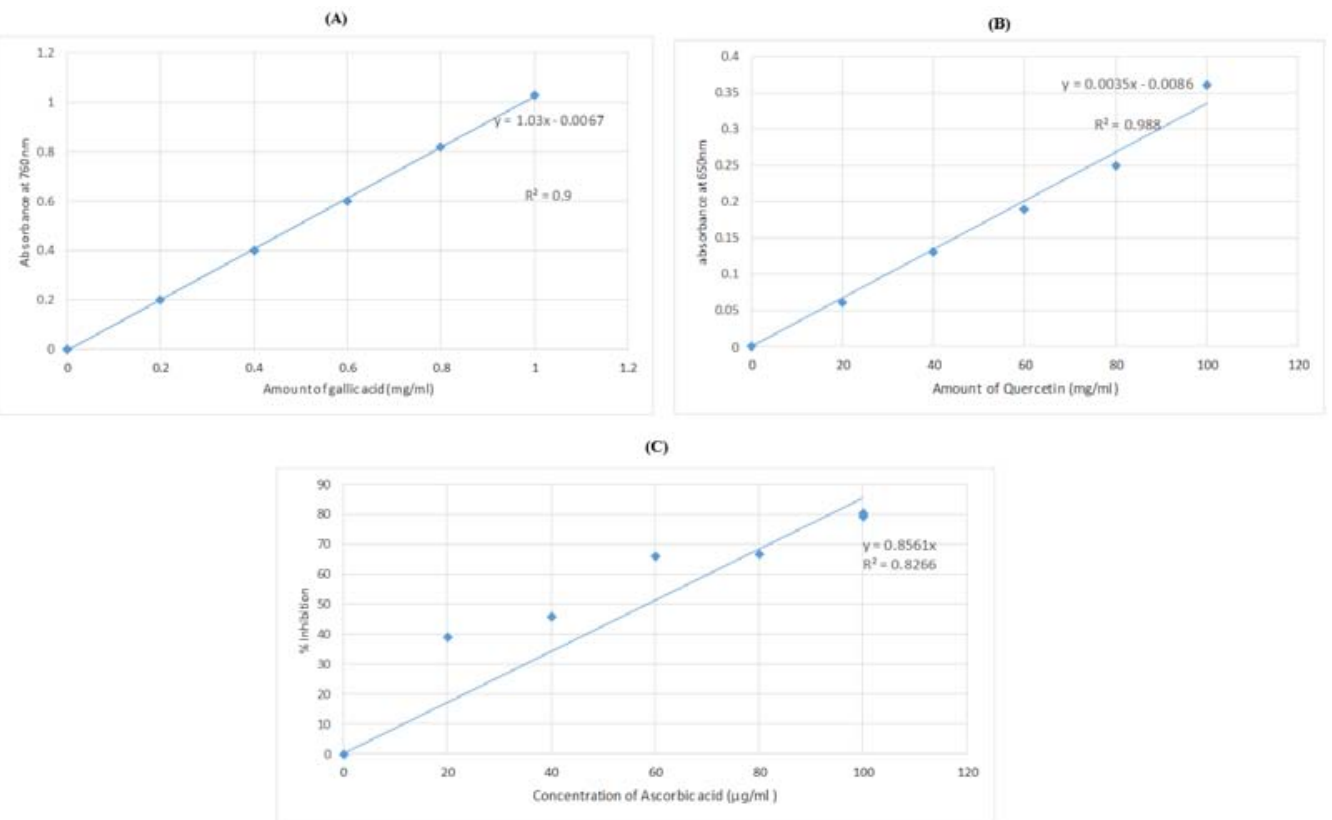

Fig. 1: Calibration curve for gallic acid (A), quercetin (B) and DPPH radical scavenging activity (C)

Table 2: Quantitative analysis of total phenols, total flavonoids, and antioxidant potential of methanolic extract of $L$. aspera leaves

\begin{tabular}{llll}
\hline Sample & Total phenols (mg GAE/g Fwt) & Total flavonoids (mg QE/g Fwt) & DPPH (\% Inhibition) \\
\hline L. aspera & $2.25 \pm 0.04$ & $1.2 \pm 0.05$ & $80.69 \pm 3.68$ \\
\hline
\end{tabular}

Results are mean \pm SEM obtained from three replicates ( $n=3$ ); GAE-Gallic acid equivalents; QE-Quercetin equivalents

\section{$\mathrm{H}_{2} \mathrm{O}_{2}$ scavenging activity}

Hydrogen peroxide is an important reactive oxygen species because of its ability to penetrate biological membranes. The toxicity of the hydroxyl radicle is reduced by scavenging of $\mathrm{H}_{2} \mathrm{O}_{2}$ by phenolics present in the plant extracts. The extract was capable of scavenging hydrogen peroxide in a concentration-dependent manner. The percentage inhibition (\% inhibition) at various concentrations of the L. aspera extracts as well as standard Ascorbic acid (100-400 $\mu \mathrm{g} / \mathrm{ml})$ was calculated. The IC50 values were found to be $224.6 \mu \mathrm{g} / \mathrm{ml}$.

\section{Lipoxygenase (LOX) inhibiting activity}

The in vitro inhibition of lipoxygenase an equivalent to the 'arachidonic acid cascades' in animals serves as a good model for screening the anti-inflammatory potential of plants [46, 47]. LOX inhibits lipid hydroperoxide formation due to scavenging of lipidoxy or lipid peroxy radical formed in the course of enzyme peroxidation. Methanolic extracts of $L$. aspera leaves were studied at 100-400 $\mu \mathrm{g} / \mathrm{ml}$, the strongest inhibition being recorded at $400 \mu \mathrm{g} / \mathrm{ml}$ (table 3 ). The IC50 values were found to be $328.2 \mu \mathrm{g} / \mathrm{ml}$ (Ascorbic acid) and $389.4 \mu \mathrm{g} / \mathrm{ml}$. The results obtained from studies on the leaf samples have shown a potential anti-inflammatory activity and may be used in various related physiological studies, aging and diseases such as cancer, neurological disorder, etc.

\section{Inhibition of heat induced albumin denaturation}

Denaturation of proteins is a well-documented cause of inflammation. As part of the investigation on the mechanism of the anti-inflammatory activity, the ability of the extract to inhibit protein denaturation was studied. L. aspera was found to be effective in inhibiting heat induced albumin denaturation with a maximum inhibition of $69 \%$ observed at $400 \mu \mathrm{g} / \mathrm{ml}$ against that of $67.3 \%$ for aspirin (table 3). The IC50 values were found to be $255.5 \mu \mathrm{g} / \mathrm{ml}$ (Ascorbic acid) and $249.62 \mu \mathrm{g} / \mathrm{ml}$ (L. aspera).

\section{Proteinase inhibitory action}

Proteinases have been implicated in arthritic reactions while leukocytes proteinase plays an important role in the development of tissue damage during inflammatory reactions. Proteinase inhibitors were found to provide protection against such inflammationinduced damage [48]. L. aspera leaf extracts exhibited significant antiproteinase activity at different concentrations as shown in table 3. Maximum inhibition of $50.4 \%$ at $400 \mu \mathrm{g} / \mathrm{ml}$ for L. aspera against that of $77.6 \%$ for Aspirin. The IC50 values were found to be 216.0 $\mu \mathrm{g} / \mathrm{ml}$ (Ascorbic acid) and $421.6 \mu \mathrm{g} / \mathrm{ml}$ (L. aspera).

\section{hRBC membrane stabilization activity}

Stabilization of RBCs membrane was studied to further establish the mechanism of anti-inflammatory action of the extract of $L$. aspera as the RBC membrane is analogous to the lysosomal membrane [49]. Acute or chronic inflammation occurs when the lysosomal enzymes enter the extracellular matrix. Membrane stabilization thus prevents further tissue inflammation. Inhibition of $64.1 \%$ for L. aspera against that of $71.3 \%$ for Aspirin was obtained. The IC50 values were found to be $206.2 \mu \mathrm{g} / \mathrm{ml}$ (Ascorbic acid) and $206.7 \mu \mathrm{g} / \mathrm{ml}$ (L. aspera). Research on the bioactivity of tannins, flavonoids and saponins have demonstrated their ability to bind to cations resulting in the stabilization of in vivo and in vitro lysosomal and RBC membranes as well as other biological molecules $[50,51]$. 
Antioxidant potentials of aqueous extract obtained from leaves of $L$. aspera were evaluated. The extracts were found to possess antiinflammatory and antioxidant effects, as determined by protein denaturation, membrane stabilization, proteinase inhibition assay, scavenging effect on the DPPH and LOX inhibition. In general, results indicated that the extract possess potent bioactivities due to the presence of substantial amount of phenolics, flavonoids, saponins and tannins.

Table 3: Evaluation of In vitro anti-inflammatory activity of $L$. aspera extracts. Aspirin was used as a standard drug. Linear regression analysis was used to calculate IC50 value

\begin{tabular}{|c|c|c|c|c|c|c|c|c|c|c|c|}
\hline \multirow[t]{2}{*}{ Sample } & \multirow[t]{2}{*}{$\begin{array}{l}\text { Conc. } \\
(\mu \mathrm{g} / \mathrm{ml})\end{array}$} & \multicolumn{2}{|c|}{$\begin{array}{l}\mathrm{H}_{2} \mathrm{O}_{2} \text { scavenging } \\
\text { activity }\end{array}$} & \multicolumn{2}{|c|}{$\begin{array}{l}\text { LOX inhibiting } \\
\text { activity }\end{array}$} & \multicolumn{2}{|c|}{$\begin{array}{l}\text { Inhibition of albumin } \\
\text { denaturation }\end{array}$} & \multicolumn{2}{|c|}{ Proteinase inhibition } & \multicolumn{2}{|c|}{ hRBC stabilization } \\
\hline & & $\begin{array}{l}\% \\
\text { inhibition }\end{array}$ & $\begin{array}{l}\mathrm{IC}_{50} \\
(\mu \mathrm{g} / \mathrm{ml})\end{array}$ & $\begin{array}{l}\% \\
\text { inhibition }\end{array}$ & $\begin{array}{l}\mathrm{IC}_{50} \\
(\mu \mathrm{g} / \mathrm{ml})\end{array}$ & $\begin{array}{l}\% \\
\text { inhibition }\end{array}$ & $\begin{array}{l}\mathrm{IC}_{50} \\
(\mu \mathrm{g} / \mathrm{ml})\end{array}$ & $\begin{array}{l}\% \\
\text { inhibition }\end{array}$ & $\begin{array}{l}\mathrm{IC}_{50} \\
(\mu \mathrm{g} / \mathrm{ml})\end{array}$ & $\begin{array}{l}\% \\
\text { stabilization }\end{array}$ & $\begin{array}{l}\mathrm{IC}_{50} \\
(\mu \mathrm{g} / \mathrm{ml})\end{array}$ \\
\hline \multirow{4}{*}{$\begin{array}{l}\text { Ascorbic } \\
\text { acid } \\
\text { standard }\end{array}$} & 100 & 18.4 & \multirow[t]{4}{*}{227.6} & 20.22 & 328.2 & 34.2 & \multirow[t]{4}{*}{255.5} & 34.7 & 216.0 & 39.1 & \multirow[t]{4}{*}{206.2} \\
\hline & 200 & 29.9 & & 32.65 & & 49.2 & & 56.2 & & 51.2 & \\
\hline & 300 & 33.5 & & 48.92 & & 56.5 & & 67.3 & & 64.2 & \\
\hline & 400 & 54.2 & & 56.92 & & 67.3 & & 77.6 & & 71.3 & \\
\hline \multirow[t]{4}{*}{ L. aspera } & 100 & $26.0 \pm 0.7$ & \multirow[t]{4}{*}{244.6} & $18.6 \pm 0.6$ & 356.37 & $32.1 \pm 1.03$ & \multirow[t]{4}{*}{249.62} & $16.6 \pm 2.96$ & 421.6 & $32.1 \pm 1.4$ & \multirow[t]{4}{*}{206.7} \\
\hline & 200 & $45.2 \pm 2.8$ & & $27.3 \pm 0.8$ & & $46.4 \pm 0.01$ & & $23.3 \pm 9.26$ & & $44.3 \pm 3.1$ & \\
\hline & 300 & $50.8 \pm 4.3$ & & $39.6 \pm 0.5$ & & $53.6 \pm 2.36$ & & $33.4 \pm 6.51$ & & $59.6 \pm 2.4$ & \\
\hline & 400 & $81.7 \pm 5.6$ & & $58.4 \pm 2.2$ & & $69.2 \pm 5.09$ & & $50.4 \pm 5.39$ & & $64.1 \pm 3.5$ & \\
\hline
\end{tabular}

Results are mean \pm SEM $(\mathrm{P}<0.05)$, obtained from three replicates.

\section{Antimicrobial activity}

In our study, the antimicrobial activity of leaf extracts of L. aspera was evaluated by disc diffusion method (table 4). Three different doses $(60$, $70,80 \%$ ) of aqueous extracts were used in the test and compared with the positive control ciprofloxacin. The antimicrobial potential of L. aspera leaf extracts was compared based on their zone of inhibition against the gram positive $(S$. aureus $)$ and gram negative bacteria $(P$. aeruginosa, K. pneumonia and E. coli).

Among gram-negative bacteria, aqueous extract of $L$. aspera showed maximum inhibition towards $P$. aeruginosa $(20 \mathrm{~mm})$ and nil inhibition for E. coli. $70 \%$ extract showed a zone of inhibition of 29 mm against $S$. aureus (table 4 ).

Table 4: Antibacterial activity of $L$. aspera extracts

\begin{tabular}{|c|c|c|c|c|c|}
\hline \multirow[t]{3}{*}{ Strains } & \multicolumn{4}{|c|}{ L. aspera extract } & \multirow[t]{2}{*}{ Ciprofloxacin } \\
\hline & $60 \%$ & $70 \%$ & $80 \%$ & UD & \\
\hline & \multicolumn{5}{|c|}{ Mean zone of inhibition $^{\mathrm{a}}(\mathrm{mm})^{\mathrm{b}}$} \\
\hline S. aureus & $14 \pm 0.2$ & $29 \pm 2.1$ & $13 \pm 0.2$ & $10 \pm 0.2$ & $22 \pm 1.6$ \\
\hline E. coli & NA & NA & NA & NA & $18 \pm 1.0$ \\
\hline K. pneumoniae & $10 \pm 0.9$ & $13 \pm 1.8$ & $13 \pm 2.1$ & $10 \pm 0.3$ & $14 \pm 1.0$ \\
\hline P. aeruginosa & $13 \pm 2.6$ & $20 \pm 1.4$ & $13 \pm 0.9$ & $13 \pm 1.1$ & $16 \pm 1.2$ \\
\hline
\end{tabular}

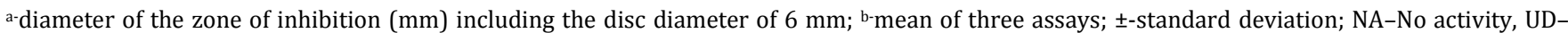
undiluted extract

Dilution seemed to increase the antibacterial activity of $L$. aspera when compared to the undiluted extract. Nevertheless, the inhibition zone produced by the commercially available positive control was larger than those produced by both the extracts. This type of activity gives an indication of the presence of antimicrobial compounds with broad spectrum or simply general metabolic toxins [52]. Further work is necessary to isolate and purify compounds in the leaf extracts, which will allow the scientific community to recommend their utilization as an accessible alternative to synthetic antibiotics.

\section{CONCLUSION}

Results indicate that L. aspera possess anti-inflammatory properties due to the strong occurrence of polyphenolic compounds such as alkaloids, flavonoids, tannins and steroids that serve as free radical inhibitors or scavenger. Compounds of the plant $\mathrm{L}$. aspera may hence be used as lead compounds for designing potent anti-inflammatory drug which can be used for treatment of various diseases.

\section{ACKNOWLEDGEMENT}

The authors are grateful to Mount Carmel College, Autonomous, Bengaluru for the provision of facilities need for conducting this project.

\section{CONFLICTS OF INTERESTS}

Declared none

\section{REFERENCES}

1. Chopra RN, Nayar SL, Chopra IC. In: Glossary of Indian medicinal plants. Vol. I. Council of Scientific and Industrial Research, New Delhi; 1956. p. 197.
2. Balunas MJ, Kinghorn AD. Drug discovery from medicinal plants. Life Sci 2005;78:431-41.

3. Tambe VD, Tambe VB, Jadhav RS. Evaluation of Leucas aspera whole plant extracts for the diuretic and laxative property. Asian J Pharm Clin Res 2016;9:118-21.

4. Hedge IC. Labiatae. In: Ali SI, Nasir YJ. editors. Flora of Pakistan. Karachi: University of Karachi Department of Botany; 1990. p. 192.

5. Santosh KM, Anil KS, Ankit S. Potential medicinal plants for lymphatic filariasis: a review. J Crit Rev 2015;2:1-6.

6. Girach RD, Aminuddin, Siddioui PA, Khan SA. Traditional plant remedies among the Kondh of district dhenkanal (Orissa). Int J Pharm 1994;32:274-83.

7. Bhandary MJ, Chandrasekhar KR, Kaveriappa KM. Medical ethnobotany of the siddis of Uttara Kannada district, Karnataka. India J Ethnopharmacol 1995;47:149-58.

8. Selvanayahgam ZE, Gnanevendhan SG, Balakrishna K, Rao RB. Antisnake venom botanicals from ethnomedicine. J Herbs Spices Med Plants Plants 1994;2:45-100.

9. Khaleque A, Huq ME, Huq MS, Mansoor MH. Chemical investigations on leucas aspera. I. Isolation of compound a, beta-sitosterol and alpha-sitosterol from the aerial parts. Sci Res 1970;7:125-7.

10. Kapur SK, Sarin YK. Medico-botanic survey of medicinal and aromatic plants of Katra valley (J. and K. state) India. Indian Drugs 1984;2:4-10.

11. John D. One hundred useful raw drugs of the kani tribes of Trivandrum forest division, Kerala, India. Int J Crude Drug Res 1984;22:17-39. 
12. Alby AB, Regi RK. Evaluation of the folk claim and identification of the active pharmacological principles in Bauhinia phoenicea leaves. Asian J Pharm Clin Res 2016;9:1-4.

13. Mukherjee PK, Saha K, Murugesan T, Mandal SC, Pal M, Saha BP. Screening of anti-diarrhoeal profile of some plant extracts of a specific region of west Bengal, India. J Ethnopharmacol 1998;60:85-9.

14. Saha K, Mukherjee PK, Das J, Mandal SC, Pal M, Saha BP. Hypoglycemic activity of Leucas lavandulaefolia Rees. In streptozotocin-induced diabetic rats. Phytother Res 1998;11:463-6.

15. Mangathayaru K, Grace FX, Bhavani M, Meignanam E, Karna RS, Kumar PD. Effect of Leucas aspera on hepatotoxicity in rats. Indian J Pharmacol 2005;37:329-30.

16. Krishnaraju AV, Rao TV, Sundararaju D, Vanisree M, Tsay HS, Subbaraju GV. Assessment of bioactivity of Indian medicinal plants using brine shrimp (Artemia salina) lethality assay. Int J Appl Sci Eng 2005;3:125-34.

17. Muthukrishnan J, Puphlantha H, Kasthuribhai K. Biological effects of four plants extracts on Culex quinquefasciatus Say. Larval stages. Insect Sci Its Appl 1997;17:389-94.

18. Okeke IN, Klugman KP, Bhutta ZA, Duse AG, Jenkins P, O'Brien TF. Antimicrobial resistance in developing countries. Part II: strategies for containment. Lancet Infect Dis 2005;5:568-80.

19. Abiramasundari P, Priya V, Jeyanthi GP, Gayathri DS. Evaluation of the antibacterial activity of cocculus hirsutus. Hygeia: J Drugs Med 2011;2:26-31.

20. Sandosskumar R, Karthikeyan M, Mathiyazhagan S, Mohankumar M, Chandrasekar G, Velazhahan R. Inhibition of Aspergillus flavus growth and detoxification of aflatoxin B1 by the medicinal plant zimmu (Allium sativum L. x Allium cepa L.). World J Microbiol Biotechnol 2007;23:1007-14.

21. Gupta SK, Banerjee AB. Screening of selected West Bengal plants for antifungal activity. Ecol Bot 1972;26:255-9.

22. Sofowara A. Medicinal plants and traditional medicine in Africa. Spectrum Books Ltd. Ibadan: Nigeria; 1993. p. 289-300.

23. Harborne JB. Phytochemical Methods. Chapman and hall Ltd, London: UK; 1973. p. 49-188, 11.

24. Ogbuewu IP. Physiological responses of rabbits fed graded levels of neem (Azadirachta indica) leaf meal. Federal University of Technology: Owerri; 2008.

25. Slinkard K, Singleton VL. Total phenol analysis: automation and comparison with manual methods. Am J Enol Vitic 1977;28:49-55.

26. Chang CC, Yang MH, Wen HM, Chern JC. Estimation of total flavonoid content in propolis by two complementary colorimetric methods. J Food Drug Anal 2002;10:178-82.

27. Braca A, Sortino C, Politi M. Antioxidant activity of flavonoids from Licania licaniaeflora. J Ethnopharmacol 2002;79:379-81.

28. Ruch RJ, Cheng SJ, Klaunig JE. Prevention of cytotoxicity and inhibition of intracellular communication by antioxidant catechins isolated from Chinese green tea. Carcinogenesis 1989;10:1003-8.

29. Axelrod BC, Cheesbrough TM, Laasko SL. Lipoxygenase from soybean. Methods Enzymol 1981;71:441-51.

30. Mizushima Y, Kobayashi M. Interaction of anti-inflammatory drugs with serum proteins, especially with some biologically active proteins. J Pharm Pharmacol 1968;20:169-73.

31. Sakat S, Juvekar AR, Gambhire MN. In vitro antioxidant and anti-inflammatory activity of methanol extract of Oxalis corniculata Linn. Int J Pharm Pharmacol Sci 2010;2:146-55.

32. Oyedepo 00, Femurewa AJ. Anti-protease and membrane stabilizing activities of extracts of Fagra zanthoxiloides, Olax subscorpioides and Tetrapleura tetraptera. Int J Pharmacogn 1995;33:65-9.
33. Azeem AK, Dilip C, Prasanth SS, Junise V, Hanan S. Antiinflammatory activity of the glandular extracts of Thunnus alalunga. Asia Pac J Med 2010;3:412-20.

34. Negi JS, Singh P, Rawat B. Chemical constituents and biological importance of swertia: a review. Curr Res Chem 2011;3:1-15.

35. Shwetha RJ, Tahareen S, Myrene RD. Antioxidant and antiinflammatory activity of Tinospora cordifolia using in vitro models. J Chem Biol Phys Sci 2006;6:497-512.

36. Rio DA, Obdululio BG, Casfillo J, Marin FG, Ortuno A. Uses and properties of citrus flavonoids. J Agric Food Chem 1997;45:4505-15

37. Okwu DE. Phytochemicals and vitamin content of indigenous spices of southeastern Nigeria. J Sustain Agric Environ 2004;6:30-7.

38. Shah BA, Qazi GN, Taneja SC. Boswellic acids: a group of medicinally important compounds. Nat Prod Rep 2009;26:72-89.

39. The United States Department of Agriculture. Center for Nutrition Policy and Promotion. Dietary Guidelines for Americans. National Academy Press: Washington DC: USA; 2010.

40. Ikyenge BA, Odiniya EO, Okhale SE. Preliminary phytochemical and pharmacognostic investigation of laggerapter odonta (DC) Sch. Bip. Int J Tradit Nat Med 2010;1:1-7.

41. Amarowicz R. Tannins: the new natural antioxidants? Eur J Lipid Sci Technol 2007;109:549-51.

42. Veitch NC. Isoflavonoids of the leguminosae. Nat Prod Rep 2007; 24:417-64.

43. Jiang $H$, Zhan WQ, Liu X, Jiang X. Antioxidant activities of extracts and flavonoid compounds from Oxytropis falcate Bunge. Nat Prod Res 2008;22:1650-6.

44. Kim HP, Son HK, Chang HW, Kang SS. Anti-inflammatory plant flavonoids and cellular action mechanisms. J Phamacol Sci 2004;96:229-45.

45. Thabrew MI, Hughes RD, McFarlane IG. Antioxidant activity of Osbeckia aspera. Phytother Res 1998;12:288-90.

46. Gardner HW. Recent investigations into the lipoxygenase pathway of plants. Biochim Biophys Acta 1991;1084:221-39.

47. Abad MJ, Bermejo P, Villar A. The activity of flavonoids extracted from Tanacetum microphyllum DC. (Compositae) on soybean lipoxygenase and prostaglandin synthetase. Gen Pharmacol 1995;26:815-9.

48. Das SN, Chatterjee S. Long-term toxicity study of ART-400. Indian Indg Med 1995;16:117-23.

49. Shenoy S, Shwetha K, Prabhu K, Maradi R, Bairy KL, Shanbhag T. Evaluation of anti-inflammatory activity of Tephrosia purpurea in rats. Asian Pac J Trop Med 2010;3:193-5.

50. El-Shabrany OA, El-Gindi OD, Melek FR, Abdel-Khalk SM, Haggig MM. Biological properties of saponin mixtures of Fagonia cretica and Fagonia mollis. Fitoterapia LXVIII 1997;68:219-22.

51. Saad S, Taher M, Susanti D, Qaralleh H, Awang AF. In vitro antimicrobial activity of mangrove plant Sonneratia alba. Asian Pac J Trop Biomed 2012;2:427-9.

52. Mohammed AA, Khalil AA, El-Beltagi HE. Antioxidant and antimicrobial properties of kaff maryam (Anastatica hierochuntica) and doum palm (Hyphaene thebaica). Grases Y Acites 2010;61:67-75.

\section{How to cite this article}

- $\quad$ Tahareen S, Shwetha R, Myrene RD. Potential antioxidant, antiinflammatory and antibacterial evaluation of extracts of leucas aspera using in vitro models. Int J Pharm Pharm Sci 2016;8(11):292-297. 